\title{
Strengths and weaknesses of forensic accounting: an implication on the socio-economic development
}

Forensic accounting

\author{
Hashem Alshurafat \\ Department of Accounting, Faculty of Economics and Administrative Sciences, \\ The Hashemite University, Zarqa, Jordan \\ Mohannad Obeid Al Shbail \\ Department of Accounting, Faculty of Economics, and Administrative Sciences, \\ Al Al-Bayt University, Mafraq, Jordan, and \\ Ebrahim Mansour \\ Department of Accounting, Faculty of Economics and Administrative Sciences, \\ The Hashemite University, Zarqa, Jordan
}

\begin{abstract}
Purpose - This review aims to provide an understanding of the strengths and weaknesses of forensic accounting education and profession.

Design/methodology/approach - This paper reviews published forensic accounting studies to explore forensic accounting strengths and weaknesses.

Findings - The strengths of forensic accounting are its benefits to students and accounting professionals, the significant need and increasing demand, the new career channels and the reduction of fraud. The weakness factors are the lack of regulation, the lack of control over the profession entry, the lack of agreement on how to teach forensic accounting, the lack of specialized research journals, the misconception of its intrinsic aim, the lack of highly qualified practitioners and educators and the lack of public recognition and occupation reputation.

Practical implications - It is hoped that this structured investigation of the factors relevant to the current and future status of forensic accounting education and profession will provide a sufficient overview of the critical issues and concerns that are important to be known for understanding and advancing the vital application of forensic accounting on the Socio-Economic Development. It is anticipated that this paper has an impact on future policy that ultimately contributes to improving business and limit fraud incidents, thus, it can contribute to business and socio-economic development.

Originality/value - The literature on forensic accounting is extensive and varied. However, there is a lack of comprehensive understanding of the strengths and weaknesses of forensic accounting. This study provided policymakers with a comprehensive understanding of forensic accounting.
\end{abstract}

Keywords Forensic accounting, Strengths and weaknesses, Education and profession

Paper type Research paper

\section{Introduction}

The endeavors to improve forensic accounting education and profession have been associated with different levels of support and failure (Arslan, 2020; Crumbley, 2019;

(C) Hashem Alshurafat, Mohannad Obeid Al Shbail and Ebrahim Mansour. Published in Journal of Business and Socio-economic Development. Published by Emerald Publishing Limited. This article is published under the Creative Commons Attribution (CC BY 4.0) licence. Anyone may reproduce, distribute, translate and create derivative works of this article (for both commercial and non-commercial purposes), subject to full attribution to the original publication and authors. The full terms of this licence

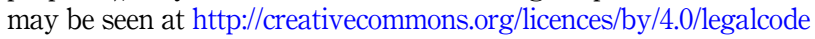


JBSED

1,2

Honigsberg, 2020; Howieson, 2018; Sahdan et al., 2020; Yang and Lee, 2020). The education and regulation of the forensic accounting profession have been examined in the prior literature (Alshurafat et al., 2019, 2020; Curtis, 2008a, b; Fleming et al., 2008; Heitger and Heitger, 2008; Jones and Dosanjh-Zucker, 2018; Kranacher et al., 2008; Rezaee and Wang, 2019; Souza, 2017; Tarr et al., 2016). However, the previous studies lack a full understanding of the benefits from and obstacles to adopt and foster forensic accounting education and profession. This paper generates an understanding of the strengths and weaknesses of forensic accounting based on the evidence that was collected from a literature review method.

Although there are prior reviews of the forensic accounting literature (Botes and Saadeh, 2018; Howieson, 2018; Huber and DiGabriele, 2015; Tiwari and Debnath, 2017), it is important to understand the factors that affect forensic accounting education and profession in both positive and negative ways. Forensic accounting literature is increased in the last few years (Honigsberg, 2020; Huber and DiGabriele, 2015; Ozili, 2020; Ramos et al., 2019). This increase has been driven by the important applications of forensic accounting for companies and their stakeholders (Sahdan et al., 2020; Yang and Lee, 2020), as well as the heightened anxiety about fraud against companies and societies (Abdullahi and Mansor, 2018; Allan et al., 2018; Association of Certified Fraud Examiners, 2016a, b, 2018; Blythe and Goodpasture, 2019; Dennis and Johnstone, 2018; Honigsberg, 2020; Öztürk and Usul, 2020; Ramos et al., 2019; Sadaf et al., 2018; Timofeyev and Jakovljevic, 2020).

Forensic accounting topics have been examined through a variety of methodologies. For example, archival data (Curtis, 2008b; Fleming et al., 2008; Grubb, 2017; Kranacher et al., 2008; Seda and Kramer, 2015), experiments (Carpenter et al., 2011) and survey research methods (Davis et al., 2010; DiGabriele, 2008; Domino et al., 2017; Hegazy et al., 2017; Smith and Crumbley, 2009). The forensic accounting literature not only represents a great variety of perspectives but also covers a wide range of research questions and issues. Despite the importance and breadth of forensic accounting literature, a comprehensive review of the literature on the strengths and weaknesses of forensic accounting is needed. The objective of this paper is to synthesize the substantial volume of empirical work in forensic accounting education and profession literature in the accounting context. This paper also aims to identify key gaps in the forensic accounting area and to propose potentially fruitful areas for future research.

More specifically, the contributions of this paper to forensic accounting literature include the following. First, reviewing the status of the forensic accounting profession in regards to accreditation of professional certifications, regulatory bodies and public recognition. Second, highlighting the incremental benefits that forensic accounting adds to accounting and auditing professions. Third, highlighting the factors that hinder the progression of forensic accounting education and profession. Fourth, highlighting the benefits of forensic accounting education to the students, the universities and prospective forensic accounting practitioners. Fifth, this review helps to provide foundational knowledge about what forensic accountants might do and what forensic accounting may provide to the clients, practitioners and society. Sixth, this paper contributes to the forensic accounting profession by providing guidelines, which may help in the process of developing forensic accounting accreditation and certifications. Finally, the aggregate contributions of this paper lead to enhance the understanding of an important part of knowledge that is directly connected to the business and socio-economic development through different tools including, fraud investigation, cybercrimes investigation, litigation support and business valuation.

This paper is organized into five main sections. The next section presents a background forensic accounting. The third section illustrates the research design. The fourth section presents the findings of this research. The final section discusses the findings and concludes this paper by emphasizing the implication of this research. 


\section{Background of forensic accounting}

The inherent aim of the forensic accounting profession is to support people, organizations and governments throughout one of the most challenging times, by providing a wide range of services that may maintain their ongoing (Howieson, 2018). Forensic accounting services are broad; thus, forensic accounting is a multidisciplinary specialization (Hegazy et al., 2017). Forensic accountants practitioners can work in different types of organizations including, insurance companies, public institutes, police forces, banks and government agencies (Tiwari and Debnath, 2017; Yogi Prabowo, 2013). Although there is an overlap between some services that forensic accounting provides (e.g. fraud detection and cybercrimes detection; litigation services and business valuation), the vast majority of research in the forensic accounting area have classified the services offered by forensic accountants into four main categories, which are litigation services (Heitger and Heitger, 2008), fraud investigation (Louwers, 2015; Van Akkeren and Buckby, 2015), computer forensic analysis (Pearson and Singleton, 2008) and business valuation (DiGabriele and Lohrey, 2016).

According to Hegazy et al. (2017), forensic accountants may act as an advisor providing professional assistance to lawyers in the litigation process or present evidence in a financial lawsuit. Litigation support services may include; dispute resolution, dispute advisory, expert witness engagements and consulting services (Curtis, 2008a; Tiwari and Debnath, 2017). Forensic accountants could provide business valuations services in some circumstances, including cases such as personal injury, risk analysis advice bankruptcy, family law, matrimonial issue, stock-based compensation and the fair value of financial reporting (DiGabriele and Lohrey, 2016; Kohn, 2014). Another area of specialty is dispute resolution, where forensic accountants are engaged with court-related and financial adversarial services (Brennan, 2005).

Forensic Accounting is a comprehensive field of professional practice for fraud investigation services. In fact, a forensic accountant plays a significant role in the process of detecting, preventing and prosecuting those individuals who are involved in criminal activity such as financial misstatement, money laundering, and identity theft (Honigsberg, 2020; Sanchez, 2012). Besides, forensic accountants are expected to deal with computerized environments and engage with a variety of work such as information technology, data mining, and computer forensics (Pearson and Singleton, 2008; Rezaee and Wang, 2019; Van Akkeren et al., 2013). Pearson and Singleton (2008) named various cybercrimes where forensic accountants can take a significant role, such as credit card fraud, online narcotic sales, telecommunications fraud, online/email extortion, online gambling, theft of computer privacy and intellectual property rights.

\section{Research design}

The conceptualization of this research design can best be described as a review paper (Petticrew and Roberts, 2008). The main objective of this paper is to provide an understanding of the strengths and weaknesses of forensic accounting education and profession based on the literature in this area. In line with the research objective, this study has taken two steps in the search for forensic accounting articles. The first step encompasses a search for keywords and keywords strings that were encompassed [forensic] and [accounting]; [forensic accounting]; [forensic accounting and expert witness]; [forensic accounting and business valuation]; [forensic accounting and fraud] and [forensic accounting and IT forensics]. The following databases were reviewed to retrieve relevant studies: ISI Web of Science; Taylor and Francis online; Elsevier; EBSCOhost; Education Resources Information Center (Eric); Emerald; J-STOR; Scopus; SSRN; Springer Link; SAGE Journals Online and Wiley Online Library.

\section{Forensic accounting}


JBSED

1,2

In addition, this first step includes a review of forensic accounting journals [1], forensic accounting special issues [2] and the journals that occasionally publish research in forensic accounting [3]. The second step encompasses snowballing search for the reference list of all identified articles in the first step. The search was limited to articles published in English. The selected articles were scattered over 16 years (2004-2020), most of the articles were published in the last decades. From the search, the relevant studies were identified and critically analyzed. The selected studies for the review were those that discussed forensic accounting education and profession.

\section{Findings}

Strengths of forensic accounting

The benefit of forensic accounting education to the students. A forensic accounting program of study may comprise a combination of various knowledge including, auditing, accounting, statistics, information technology (IT), law sociology and psychology (Kresse, 2008). Moreover, forensic accounting students would be exposed to a variety of useful knowledge, abilities, and skills during their period of study. Besides, a successful forensic accountant has to possess a set of skills, including analytical, communication and investigative skills (DiGabriele, 2008; LaSalle, 2007; McMullen and Sanchez, 2010; Tiwari and Debnath, 2017). Brickner et al. (2010, p. 696) listed that after passing a forensic accounting course, students indicate significant improvement in their acquisition of fraud detection skills and abilities related to "(1) gathering, organizing, and evaluating evidence; (2) employing various investigative tools to identify evidence of fraud (i.e. tax evasion); (3) conducting interviews for evidence-gathering purposes and (4) communication."

Experimental studies on the benefits of forensic accounting education to the students have revealed that students with anti-fraud knowledge and skills rise their employment opportunities after graduation (Carpenter et al., 2011). Students with forensic accounting education are deemed more beneficial to their institutions. LaSalle (2007) stated that the students who were taught the fraud triangle theory in a forensic accounting course performed fewer fraud discovery errors than other students. This opinion has been reinforced by Lehmann (2015), who indicated that graduates with forensic accounting education had come back after graduation to state that the study of forensic accounting courses promoted them to be more proficient in their work through gaining the knowledge of a fraud risk assessment and fraud detection.

The benefit of forensic accounting to students is multiple. For example, Carpenter et al. (2011) conclude that the forensic accounting course enhances the students' level of skepticism. Their longitudinal experiment submits that forensic accounting education equips students with higher performance of fraud-risk assessment. In another example, Lee et al. (2015) reveal that students with forensic accounting education show higher levels of creativity than other students. Heitger and Heitger (2008) assert that the broad spectrum of forensic accounting services may attract students to engage in forensic accounting education and consequently may enhance their understanding of the new opportunities that they may encounter. Again, forensic accounting competencies are not only helpful for prospective forensic accountants but are also helpful to all accounting students regardless of their selected career path.

The value of the profession. Forensic accounting renders value to accountants and auditors when they add some of the forensic accounting competencies to their competencies set. Crumbley et al. (2004) claimed that the significance of the forensic accounting profession is derived from the adjudicative and investigative roles of the forensic accountants, particularly in today's litigious business environment and the growing occurrence of fraud and financial dishonesty. Forensic accounting is deemed a vital profession as it incorporates a blend of 
knowledge including, accounting, auditing, law, finance, information technology and criminology. Prior researchers have affirmed that the benefits of forensic accounting originated from the broad spectrum of duties that are encapsulated under the forensic accounting umbrella (Alshurafat et al., 2020; Botes and Saadeh, 2018; Hegazy et al., 2017; Honigsberg, 2020; Kresse, 2008; Tiwari and Debnath, 2017).

Significant need and increasing demand. The studies on the availability of forensic accounting education are multiple (Alshurafat et al., 2020; Kramer et al., 2017; Rezaee et al., 2016; Seda and Kramer, 2014, 2015; Wang et al., 2016). Recently, the need for forensic accountants, forensic accounting services and forensic accounting education has been increased (Tiwari and Debnath, 2017). Consequently, the number of forensic accounting education programs has also been increased (Alshurafat et al., 2019; Seda and Kramer, 2008). This increase is seen in specific contexts around the world. For example, Alshurafat et al. (2019) reported an increasing number of universities teaching forensic accounting in the Australian context. Similarly, Seda and Kramer (2014) find that universities in the USA and international accounting have greatly increased the availability of forensic accounting education.

In addition, the number of forensic accounting firms has been increased (Hegazy et al., 2017; Van Akkeren et al., 2013; Van Akkeren and Tarr, 2014). The increase in forensic accounting profit in the USA is greater than the overall national GDP increase (Huber, 2014). Huber (2012) argued that forensic accounting in the USA is receiving growing interest from different stakeholders such as academics and practitioners. This increase in forensic accounting firms has been noticed in different context worldwide such as Australia (Tarr et al., 2016; Van Akkeren and Tarr, 2014), China (Rezaee et al., 2016; Wang et al., 2016), United Kingdom (Hegazy et al., 2017), New Zealand (Botes and Saadeh, 2018), Canada (Gosselin, 2014) and Ireland (Brennan, 2014).

New career channels. Current studies have reported notable barriers within the forensic accounting profession and forensic accounting certifications (Huber, 2014). Though there are some obstacles associated with the regulation of forensic accounting accreditations, there are many organizations that offer several professional certifications. Domino et al. (2017) stated that any forensic accountant who wants to be accredited could hold one of 16 certifications available for forensic accountants. Furthermore, there are growing numbers of organizations that issue certifications in forensic accounting (Huber, 2014).

Boyd et al. (2009) criticize the requirements for the Certified Fraud Examiner (CFE) as a major certification in the area of forensic accounting. According to Boyd et al. (2009, p. 87), CFE practitioners cover duties such as "resolving cases involving fraud, gathering evidence, obtaining statements and filling out reports, giving court testimony to findings, and aiding authorities in the detection and prevention of fraud." Forensic accounting practitioners can work in government agencies, auditing firms, banks, and financial companies, non-profit organizations, small and medium entities or specialized firms to provide forensic accounting services.

Fraud reduction. As fraud increases and auditors fail to detect the fraud perpetrators, forensic accounting gains legitimacy as a profession that proposes a set of tools to detect fraud and fraud perpetrators (Honigsberg, 2020; Nawawi and Salin, 2018; Yeoh, 2014). Fraud is a threat to organizations of all types and sizes in all parts of the world. The 2018 Report to the Nations, which is conducted by the Association of Certified Fraud Examiners, revealed 2,690 occupational fraud cases from 125 countries in a total of more than 7 billion dollars for all cases and 130,000 dollars per case on average. Van Akkeren and Buckby (2015) attribute the collapse of Enron, Tyco, WorldCom, Adelphia, to corporate fraud. Tiwari and Debnath (2017) revealed that there is an increase in the number of fraud and fraudulent activities worldwide, emphasizing the visibility of forensic accounting services.
Forensic
accounting

139 
JBSED

1,2

Proper forensic accounting education can ensure that employees and customers are aware of the consequences of fraud and financial misconduct on the companies (Honigsberg, 2020). Also, forensic accounting education can inform the employees about the steps needed to protect information that can lead to financial crime. Forensic accountants are equipped with knowledge and skills to detect fraudulent from committing their fraud incidents. Mehta and Bhavani (2017) demonstrated how forensic accounting practitioners utilize different forensic tools to detect fraud. These tools include statistical abnormalities measurements such as the Altman Z-Score, Benford's Law Model, Beneish eight-factored and five-factored variables. Furthermore, these tools may also include an accounting-focused approach that focuses on financial statement analysis. Consequently, the incorporation of modern forensic accounting techniques in accounting and auditing is perceived as essential to deal effectively with the problem of discovering ingenious fraud schemes arising from audit failure to detect frauds (Honigsberg, 2020).

\section{Weaknesses of forensic accounting}

Lack of professional regulations (standards and standard setters). In forensic accounting literature, there are variations in the profession regulations across countries (Hegazy et al., 2017; Louwers, 2015; Tarr et al., 2016). Also, there is a lack of empirical evidence in the literature that identifies the regulations for forensic accounting firms (Huber, 2012). Hegazy et al. (2017) found noticeable differences between forensic accounting regulations in the UK and the US According to Brennan (2014), forensic accounting in Ireland is considerably less regulated than in the US and probably comparable to countries such as Canada, UK and Australia. In comparison, the forensic accounting profession is well established in the US and Canada (Gosselin, 2014).

The first organized, professional forensic accounting body was founded in the US in 1989 - the Association of Certified Fraud Examiners (ACFE), which issued its first standards in 1991, aimed at facilitating certified fraud examiners in their engagements, and related to independence and objectivity, qualifications, due professional care in fraud examination, and confidentiality. The ACFE was followed by the emergence of several other forensic accounting bodies in the US (Huber, 2014). However, no one organization is regulated under either federal or state law. They are free to issue certification and to establish their membership criteria (Huber, 2014).

No control over the profession entry. There is a difference regarding the required qualifications of forensic accountants within countries (Howieson, 2018). Hegazy et al. (2017) show that there is no particular law controls the qualifications and requirements of entry into the forensic accounting profession in the United Kingdom, not even a license that demands an examination. Besides, the same problem remains within Ireland and Australia contexts (Brennan, 2005, 2014; Van Akkeren and Tarr, 2014). Many practitioners claim that they are forensic accounting practitioners without any formal qualifications. Therefore, anyone can claim the title of a forensic accountant. Thus, the forensic accounting profession is left open to non-accounting-based experts (Van Akkeren et al., 2013). The absence of control over profession entry has been mentioned by Crumbley et al. (2004), who claimed that there are no comprehensive standards or generally accepted rules that govern the forensic accounting profession in the world. Although it has taken more than 25 years to understand this problem, it has not been solved yet.

Inconsistency in forensic accounting education contents. Auditing and accounting courses are unable to offer appropriate knowledge to students in terms of integrating accounting knowledge with other interdisciplinary filed (e.g. fraud investigation and litigation support) (Kresse, 2008). There are contradictory views amongst stakeholders groups (academics, practitioners, and service users) toward several issues related to the education of forensic 
accounting, including offering mode, knowledge contents and teaching pedagogies (Wang et al., 2016). This argument has been supported by Kramer et al. (2017), who find significant differences between the educators' and practitioners' perceptions of forensic accounting content and preferred teaching methods. In addition, Seda and Kramer (2014) report that there is no consistency in the delivery modes of forensic accounting education and how to integrate forensic accounting into the accounting curriculum.

Rezaee et al. (2004) stated that educators gave more interest than practitioners did in the inclusion of fraud examination, including topics such as fraud types, fraud elements, business red flags, and anti-fraud measures. While practitioners recognized the importance of integration of fraud education, they gave more emphasis on topics related to finding hidden assets, conflicts of interest, effective report writing, expert testimony, expert witness techniques, compliance with legislation and regulations and litigation consulting techniques.

Lack of research and research journals. Most forensic accounting researchers focus on the narrow approach of forensic accounting (Howieson, 2018), which mainly considers fraud investigation topics. Thus, forensic accounting faces a real problem to evolve as a discipline and profession (Huber and DiGabriele, 2015). In the theoretical contribution to forensic accounting research, the notable theoretical contributions and theoretical applications in forensic accounting research are the fraud triangle theory that has been subsequently developed by adding the fourth element to be fraud diamond theory (Free, 2015). However, there is a need to expand the use of various theories in forensic accounting research (Huber and DiGabriele, 2015). In the methodological contribution to forensic accounting research, Huber and DiGabriele (2015) indicate that quantitative methods make up the largest percentage of research methods published in forensic accounting journals. The lack of both theoretical and methodological contributions of forensic accounting research is referred to as the lack of specialized forensic accounting journals.

Botes and Saadeh (2018) demonstrate that the prevalence of the term forensic accounting in publications is limited. Thus there are opportunities for academics to publish in the forensic accounting area. Currently, there are very limited forensic accounting research journals or research journals that might be interested in publishing forensic accounting studies. The lack of research journals affects the evolving process of forensic accounting because research is the main way to provide both theoretical and practical contributions. Lacking the proper number of forensic accounting journals limits the ranking for the forensic accounting journal as they may not receive a high citation on what they publish. Therefore, forensic accounting topics will not be attractive to the researchers and ditto to the practitioners.

The misconception of the intrinsic aim of forensic accounting. In essence, there are major differences between traditional accounting, auditing and forensic accounting. Traditional accounting encompasses three main activities, namely, identification and recognition, measurement and recording, disclosure and communication of financial data and information to its users (Weygandt et al., 2019). The nature of auditors' engagements is to offer an independent opinion on whether financial statements are fairly presented (Crain $e t$ al., 2019). On contrary, the intrinsic aim of forensic accounting is to provide adjudicative, evaluation and investigative services, which most likely end as a testimony in the court regarding the financial misconduct matters (Muehlmann et al., 2012). In the literature, forensic accounting is defined in two different approaches. The first approach has provided a narrowed definition, which covers the in-courtroom role of forensic accountants (Botes and Saadeh, 2018). The second approach has provided a broad definition, including the adversarial, evaluation and investigative roles of forensic accountants (Rezaee et al., 2004). Botes and Saadeh (2018) identify changes in using forensic accounting terms and conclude that the narrowed approach prevails. Huber (2013) stated that there is a variation in the forensic accounting definitions, and in some cases, the definitions are contradictory, especially as it pertains to the inclusion of fraud. Smith and Crumbley (2009) highlight some conceptual differences between

\section{Forensic accounting}


JBSED

1,2

fraud examination and forensic accounting. Forensic accounting is broad and far-ranging. Accounting curriculum instructors must decide whether they should build their degrees on a fraud model, a more broad-ranging forensics model or an aggregation of the two approaches.

Forensic accounting has undergone several significant transformations over the past 40 years (Williams, 2006). The narrow view of forensic accounting dominated the literature until the beginning of the 1990s. Over the last three decades, the usage of the term seems to have changed in response to large-scale corporate scandals and the growing application of forensic accounting services (Botes and Saadeh, 2018; Tarr et al., 2016; Van Akkeren and Buckby, 2015). Over the last decade, the definitions of forensic accounting seem to embrace a more comprehensive approach to defining forensic accounting based on its results (Botes and Saadeh, 2018). Both the narrowed and broad approaches present shortcomings and fail to provide a comprehensive definition of forensic accounting. Therefore, the shortcomings to provide an accurate definition of the forensic accounting profession led to the threat of misconception of the intrinsic aim of forensic accounting.

Need high qualified practitioners and educators. Many researchers have examined the required skills of forensic accountants (Davis et al., 2010; DiGabriele, 2008; Howieson, 2018; McMullen and Sanchez, 2010). McMullen and Sanchez (2010) investigate the preliminary skills, education requirements and training requirements for forensic accountants. They found that analytical skills, computer skills, investigative skills and legal roles are important for forensic accountants. Instructors should consider these skills when designing forensic accounting curricula. Thus, students can find forensic accounting curricula valuable.

Finding qualified instructors to teach forensic accounting is not that easy task for university administrators. Several reasons have led to the complexity of finding qualified instructors to teach forensic accounting. The first reason is that forensic accounting contains a broad range of services that need a specialized instructor (Souza, 2017), in some cases, a team of specialized instructors. Both work-based and individual attributes are required by the forensic accounting practitioner, mutually with a broad range of sophisticated competencies. Forensic services expect useful work-based competencies such as oral and written communication skills, technological and analytical skills (Van Akkeren et al., 2013). A second reason is that the need for highly qualified practitioners could cost too much for many entities.

Lack of public recognition and occupation reputation. One of the weaknesses that are facing forensic accounting is the lack of public recognition (Williams, 2006). Forensic accountants should seek to heighten their occupation reputation as it determines their carrier success. Forensic accounting service is still new to most businesses and even to the public. The lack of public recognition leads to confusion among the public about the nature of the services that forensic accountants perform. Therefore, the importance of the service is ignored. In pursuit of the new market of forensic accounting, professional accountants have capitalized upon their public image, promoting forensic accounting services. To gain the public confidence and recognition of forensic accounting, educators need to make dramatic changes given the current state of the profession,

\section{Conclusion and discussion: avenues for improvement}

As shown in Table 1, a qualitative review of the literature yielded 12 themes distributed between the strengths and weaknesses points.

Based on the previous literature review and this paper's analysis, forensic accounting is a field with many applications. From its roots in the fields of accounting and auditing and its multidisciplinary nature, forensic accounting combines financial, technological, adjudicative and investigative knowledge (Hegazy et al., 2017; Howieson, 2018). The broad knowledge and competencies that the students learn in forensic accounting courses empower them to be more informative in areas that a traditional accounting course would not cover. Articulating 
forensic accounting knowledge with accounting and auditing enhances the value of service that might be provided to clients. Therefore, the increasing need and demand for forensic accounting services and education are justified by the incremental benefit that forensic accounting adds to the accounting profession and accounting students.

Based on the above-mentioned strength points, many opportunities are available to the forensic accounting stakeholders such as students, educators, practitioners, and clients. Regarding the students, they would be able to enhance their knowledge in accounting by mixing their accounting knowledge with the holistic knowledge of forensic accounting or at least with one part of forensic accounting knowledge. For example, a student who engages in forensic accounting education might be able to use accounting for fraud detection purposes, expert witness in lawsuits, IT fraud detection or business valuation purposes. In the same way, educators might add competitive value to their accounting curriculum by integrating forensic accounting knowledge with their students (LaSalle, 2007; Pearson and Singleton, 2008).

In regards to the practitioners and clients, forensic accounting equips its practitioners with many tools to provide specific services that would not be provided by accountants and auditors. The broad set of forensic accounting services is beneficial to the clients, particularly in terms of fraud reduction. Another reason that made forensic accounting valuable to the stakeholders is that forensic accounting helps in reducing the fraud risk. The fraud surveys during recent years indicate that companies and individuals worldwide suffer a lot from fraud (Van Akkeren and Buckby, 2015). Therefore, forensic accounting has been recognized as a useful profession to deter fraud and reduce the risk of being a fraud victim.

The review of the weaknesses of forensic accounting shows that the profession and education of forensic accounting are facing various impediments. The lack of regulators and standards gave those who are not qualified to practice forensic accounting services the opportunity to do so. That is because of the absence of forensic accounting bodies with strict rules to govern the entry to the forensic accounting profession. As forensic accounting, a profession with high intellectual techniques (Huber, 2013), the practitioners of the profession should be highly qualified and equipped with a set of important competencies. Thus, the lack of strict rules to refine the new entrants to the profession results in accepting unqualified individuals in the profession of forensic accounting (Van Akkeren et al., 2013). Consequently, the overall reputation of the forensic accounting profession and public recognition for it are threatened.

The trends toward using the narrowed definition and broad definition approach heighten the misconception of what forensic accounting is and what forensic accountants do. Therefore, forensic accounting has been seen from different angles (Botes and Saadeh, 2018). Consequently, forensic accounting educational content is significantly varied. Some universities have adopted the narrowed definition of forensic accounting. Also, they have exclusively exposed their student to the fraud investigation part of forensic accounting.

\begin{tabular}{ll}
\hline Strength & Weakness \\
\hline (1) The benefit of forensic accounting & (1) Lack of professional regulations (standards and standard \\
education to the students & (2) Notters) \\
(2) The value of the profession & (3) Inconsistency in forensic accounting education contents \\
(3) Significant need and increasing & (4) Lack of research and research journals \\
demand & (5) The misconception of the intrinsic aim of forensic \\
(4) New career channels & (6) Need high qualified practitioners and educators \\
(5) Fraud reduction & (7) Lack of public recognition and occupation reputation
\end{tabular}

Table 1. summary of the findings 
JBSED

1,2

144

Where other universities have a broad definition of forensic accounting and have exposed their student to all part of forensic accounting (Botes and Saadeh, 2018; Curtis, 2008a, b; Fleming et al., 2008; Heitger and Heitger, 2008; Kranacher et al., 2008; Pearson and Singleton, 2008). Also, there is a lack of forensic accounting research and research journal. These factors together are facing the improvement of forensic accounting education and profession.

There are several avenues for the improvement of forensic accounting education and profession. First, enhance the professionalism level of forensic accounting by establishing ad hoc forensic accounting associations. Second, maintain a high quality of forensic accounting services by controlling the entry to the profession. Third, enhance the quality of forensic accounting education through developing consistent education, which is corresponded to the real work of forensic accounting. Fifth, elevate the research outputs that are relevant to forensic accounting by encouraging researchers to engage in this field and issuing new forensic accounting research journals. Finally, enhancing the reputation of forensic accounting as a profession by increasing the public recognition for it through offering workshops that enhance the public awareness of fraud and its consequences on the society and how forensic accountants could help to deter the fraud risk.

Forensic accounting is emerging as a field of knowledge, where many aspects still need more exploration. Hence, this paper adopted a literature review method to understand the discourse encompassing the forensic accounting profession and education. This paper sets a stage for further studies into this important topic. The paper can be enhanced by conducting an empirical study to better understand the professional and education of forensic accounting. Furthermore, future researchers can contribute to the understanding of forensic accounting as it is directly connected to business and socio-economic development through different forensic accounting tools.

\section{Notes}

1. Forensic accounting research journals - the Journal of Forensic and Investigative Accounting; the Journal of Forensic Studies in Accounting and Business and the Journal of Forensic Accounting Research.

2. The Pacific Accounting Review, Volume 30, issue 2; the Accounting Research Journal Volume 28, Issue 1. Issues in Accounting Education Volume 23, Issue 4.

3. The Accounting Review; Contemporary Accounting Research; Accounting, Organizations and Society; Journal of Accounting Research; Journal of Accounting and Economics; Journal of Accounting Literature; Review of Accounting Studies; the British Accounting Review; Journal of Accounting and Public Policy; Journal of Accounting, Ethics and Public Policy; Research in Accounting Regulation; International Journal of Accounting, Auditing and Performance Evaluation; and the Journal of Business Ethics.

\section{References}

Abdullahi, R. and Mansor, N. (2018), "Fraud prevention initiatives in the Nigerian public sector", Journal of Financial Crime, Vol. 25 No. 2, pp. 527-544, doi: 10.1108/JFC-02-2015-0008.

Allan, D.M., Kelly, A. and Stephenson, A. (2018), "The prominence of fraud in New South Wales metropolitan media reporting", Crime, Law and Social Change, Vol. 70 No. 5, pp. 603-619, doi: 10.1007/s10611-018-9784-9.

Alshurafat, H., Beattie, C., Jones, G. and Sands, J. (2019), "Forensic accounting core and interdisciplinary curricula components in Australian universities: analysis of websites", Journal of Forensic and Investigative Accounting, Vol. 11 No. 2-Special Edition, pp. 353-365.

Alshurafat, H., Beattie, C., Jones, G. and Sands, J. (2020), "Perceptions of the usefulness of various teaching methods in forensic accounting education", Accounting Education, Vol. 29 No. 2, pp. 177-204, doi: 10.1080/09639284.2020.1719425. 
Arslan, Ö. (2020), "The forensic accounting profession and the process of its development in the world", Contemporary Issues in Audit Management and Forensic Accounting, Emerald Publishing.

Association of Certified Fraud Examiners (2016a), "Investigation planning and conducting a fraud examination", available at: https://www.acfe.com/uploadedFiles/Shared_Content/Products/ Books_and_Manuals/U.S.\%20Sample\%20Chapter_2016.pdf.

Association of Certified Fraud Examiners (2016b), "Report to the nations on occupational fraud and abuse", available at: http://www.acfe.com/rttn2016.aspx.

Association of Certified Fraud Examiners (2018), "Report to the nations Global study on occupational fraud and abuse", available at: http://www.acfe.com/report-to-the-nations/2018/.

Blythe, S. and Goodpasture, J.E. (2019), "Nursing home fraud schemes: forensic accounting lessons from litigation", International Journal of Healthcare Management, Vol. 14 No. 1, pp. 91-98, doi: 10.1080/20479700.2019.1616138.

Botes, V. and Saadeh, A. (2018), "Exploring evidence to develop a nomenclature for forensic accounting", Pacific Accounting Review, Vol. 30 No. 2, pp. 135-154, doi: 10.1108/PAR-122016-0117.

Boyd, D.T., Boyd, S.C. and Berry, P. (2009), "A primer for accounting certification: complete analysis of the process with listing of sources", American Journal of Business Education, Vol. 2 No. 7, pp. 83-96.

Brennan, N.M. (2005), "Accounting expertise in litigation and dispute resolution”, Journal of Forensic Accounting, Vol. 2, pp. 13-35.

Brennan, N.M. (2014), "Forensic accounting in a constitutional parliamentary democracy: the case of Ireland", Journal of Forensic and Investigative Accounting, Vol. 6 No. 3-Special International Issue, pp. 62-97.

Brickner, D.R., Mahoney, L.S. and Moore, S.J. (2010), "Providing an applied-learning exercise in teaching fraud detection: a case of academic partnering with IRS Criminal Investigation", Issues in Accounting Education, Vol. 25 No. 4, pp. 695-708, doi: 10.2308/iace.2010.25.4.695.

Carpenter, T.D., Durtschi, C. and Gaynor, L.M. (2011), "The incremental benefits of a forensic accounting course on skepticism and fraud-related judgments", Issues in Accounting Education, Vol. 26 No. 1, pp. 1-21, doi: 10.2308/iace.2011.26.1.1.

Crain, M.A., Hopwood, W.S., Gendler, R.S., Young, G.R. and Pacini, C. (2019), Essentials of Forensic Accounting, John Wiley and Sons, New York.

Crumbley, L. (2019), "Forensic accounting is more than just fraud", available at: https://www. researchgate.net/publication/338084263_Forensic_Accounting_Is_More_Than_Just_Fraud (accessed 1 September 2020).

Crumbley, L., Rezaee, Z. and Elmore, R.C. (2004), "Forensic accounting education: a survey of academicians and practitioners", Journal of Forensic Accounting, Vol. 11 No. 2, pp. 181-202.

Curtis, G.E. (2008a), "Legal and regulatory environments and ethics: essential components of a fraud and forensic accounting curriculum", Issues in Accounting Education, Vol. 23 No. 4, pp. 535-543, doi: 10.2308/iace.2008.23.4.535.

Curtis, G.E. (2008b), "The model curriculum in fraud and forensic accounting and economic crime programs at Utica college", Issues in Accounting Education, Vol. 23 No. 4, pp. 581-592, doi: 10. 2308/iace.2008.23.4.581.

Davis, C., Farrell, R. and Ogilby, S. (2010), "Characteristics and skills of the forensic accountant", available at: https://competency.aicpa.org/media_resources/209049-characteristics-and-skills-ofthe-forensic-accounta.

Dennis, S.A. and Johnstone, K.M. (2018), "A natural field experiment examining the joint role of audit partner leadership and subordinates' knowledge in fraud brainstorming", Accounting, Organizations and Society, Vol. 66, pp. 14-28, doi: 10.1016/j.aos.2018.02.001. 
JBSED

1,2

DiGabriele, J.A. (2008), "An empirical investigation of the relevant skills of forensic accountants", Journal of Education for Business, Vol. 83 No. 6, pp. 331-338, doi: 10.3200/JOEB.83.6.331-338.

DiGabriele, J.A. and Lohrey, P.L. (2016), "The valuation of economic damages: a case study for the forensic accountant", Journal of Forensic and Investigative Accounting, Vol. 8 No. 2, pp. 338-348.

Domino, M.A., Giordano, G. and Webinger, M. (2017), "An investigation of the factors that impact the perceived value of forensic accounting certifications", Journal of Forensic and Investigative Accounting, Vol. 9 No. 1, pp. 637-653.

Fleming, A.S., Pearson, T.A. and Riley, R.A. Jr (2008), "West Virginia University: forensic accounting and fraud investigation (FAFI)", Issues in Accounting Education, Vol. 23 No. 4, pp. 573-580, doi: 10.2308/iace.2008.23.4.573.

Free, C. (2015), "Looking through the fraud triangle: a review and call for new directions", Meditari Accountancy Research, Vol. 23 No. 2, pp. 175-196, doi: 10.1108/MEDAR-02-2015-0009.

Gosselin, M. (2014), "Forensic accounting in Québec: the context of a distinct society in Canada", Journal of Forensic and Investigative Accounting, Vol. 6 No. 3, pp. 48-61.

Grubb, F. (2017), “Colonial Virginia's paper money regime, 1755-74: a forensic accounting reconstruction of the data", Historical Methods: A Journal of Quantitative and Interdisciplinary History, Vol. 50 No. 2, pp. 96-112, doi: 10.1080/01615440.2016.1256241.

Hegazy, S., Sangster, A. and Kotb, A. (2017), "Mapping forensic accounting in the UK", Journal of International Accounting, Auditing and Taxation, Vol. 28, pp. 43-56, doi: 10.1016/j.intaccaudtax. 2016.12.004.

Heitger, L.E. and Heitger, D.L. (2008), "Incorporating forensic accounting and litigation advisory services into the classroom", Issues in Accounting Education, Vol. 23 No. 4, pp. 561-572, doi: 10. 2308/iace.2008.23.4.561.

Honigsberg, C. (2020), "Forensic accounting", Annual Review of Law and Social Science, Vol. 16, doi: 10. 1146/annurev-lawsocsci-020320-022159.

Howieson, B. (2018), "What is the 'good' forensic accountant? A virtue ethics perspective", Pacific Accounting Review, Vol. 30 No. 2, pp. 155-167, doi: 10.1108/PAR-01-2017-0005.

Huber, W. (2012), "Is forensic accounting in the United States becoming a profession?", Journal of Forensic and Investigative Accounting, Vol. 4 No. 1, pp. 255-284.

Huber, W. (2013), "Should the forensic accounting profession be regulated?", Research in Accounting Regulation, Vol. 25 No. 1, pp. 123-132, doi: 10.1016/j.racreg.2012.11.006.

Huber, W. (2014), "What is the value of multiple certifications in forensic accounting?", Journal of Forensic and Investigative Accounting, Vol. 7 No. 2, pp. 113-143.

Huber, W. and DiGabriele, J.A. (2015), "Topics and methods in forensic accounting research", Accounting Research Journal, Vol. 28 No. 1, pp. 98-114, doi: 10.1108/ARJ-08-2014-0071.

Jones, C.G. and Dosanjh-Zucker, K. (2018), "Using a forensic accounting novel to increase student engagement with accounting ethics and the profession", Journal of Forensic and Investigative Accounting, Vol. 10 No. 2, pp. 250-257.

Kohn, M. (2014), "Finding the hidden cash of a real estate developer", American Journal of Family Law, Vol. 28 No. 3, pp. 117-118, available at: http://ezproxy.usq.edu.au/login?url=http://search. ebscohost.com/login.aspx?direct $=$ true $\& \mathrm{db}=$ sxi\&AN $=97489175 \&$ site $=$ ehost-live .

Kramer, B., Seda, M. and Bobashev, G. (2017), "Current opinions on forensic accounting education", Accounting Research Journal, Vol. 30 No. 3, pp. 249-264, doi: 10.1108/ARJ-06-2015-0082.

Kranacher, M.J., Morris, B.W., Pearson, T.A. and Riley, R.A. Jr (2008), "A model curriculum for education in fraud and forensic accounting", Issues in Accounting Education, Vol. 23 No. 4, pp. 505-519, doi: 10.2308/iace.2008.23.4.505.

Kresse, W.J. (2008), "The Saint Xavier University graduate program in financial fraud examination and management", Issues in Accounting Education, Vol. 23 No. 4, pp. 601-608, doi: 10.2308/iace. 2008.23.4.601. 
LaSalle, R.E. (2007), "Effects of the fraud triangle on students' risk assessments", Journal of Accounting Education, Vol. 25 Nos 1-2, pp. 74-87, doi: 10.1016/j.jaccedu.2007.03.002.

Lee, C.C., Cefaratti, M. and Rose-Green, E. (2015), "The incremental benefit of a forensic accounting course to creativity", Journal of Forensic and Investigative Accounting, Vol. 8 No. 1, pp. 157-167.

Lehmann, C.M. (2015), “Asset misappropriation schemes: short cases for use in the classroom”, Journal of Forensic and Investigative Accounting, Vol. 7 No. 2, pp. 340-362.

Louwers, T.J. (2015), "The past, present, and future (?) of crime-related forensic accounting methodology", Accounting Research Journal, Vol. 28 No. 1, pp. 4-9, doi: 10.1108/ARJ-04-2015-0047.

McMullen, D.A. and Sanchez, M.H. (2010), "A preliminary investigation of the necessary skills, education requirements, and training requirements for forensic accountants", Journal of Forensic and Investigative Accounting, Vol. 2 No. 2, pp. 30-48.

Mehta, A. and Bhavani, G. (2017), "Application of forensic tools to detect fraud: the case of Toshiba", Journal of Forensic and Investigative Accounting, Vol. 9 No. 1, pp. 692-710.

Muehlmann, B.W., Burnaby, P.A. and Howe, M.A. (2012), "The use of forensic accounting experts in tax cases as identified in court opinions", Journal of Forensic and Investigative Accounting, Vol. 4 No. 2, pp. 1-34.

Nawawi, A. and Salin, A.S.A.P. (2018), "Whistle blowing intentions-evidence from Malaysian PLC", International Journal of Law and Management, Vol. 60 No. 5, pp. 1111-1125, doi: 10.1108/IJLMA04-2017-0096.

Ozili, P.K. (2020), “Advances and issues in fraud research: a commentary”, Journal of Financial Crime, Vol. 27 No. 1, pp. 92-103, doi: 10.1108/JFC-01-2019-0012.

Öztürk, M.S. and Usul, H. (2020), "Detection of accounting frauds using the rule-based expert systems within the scope of forensic accounting", Contemporary Issues in Audit Management and Forensic Accounting, Emerald Publishing.

Pearson, T.A. and Singleton, T.W. (2008), "Fraud and forensic accounting in the digital environment", Issues in Accounting Education, Vol. 23 No. 4, pp. 545-559, doi: 10.2308/iace.2008.23.4.545.

Petticrew, M. and Roberts, H. (2008), Systematic Reviews in the Social Sciences: A Practical Guide, John Wiley and Sons, Malden.

Ramos, M.M., Sánchez Medina, A.J. and Blázquez Santana, F. (2019), "Research topics in accounting fraud in the 21st century: a state of the art", Sustainability, Vol. 11 No. 6, p. 1570, doi: 10.3390/ su11061570.

Rezaee, Z. and Wang, J. (2019), "Relevance of big data to forensic accounting practice and education", Managerial Auditing Journal, Vol. 3 No. 3, pp. 268-288, doi: 10.1108/MAJ-08-2017-1633.

Rezaee, Z., Crumbley, D.L. and Elmore, R.C. (2004), "Forensic accounting education", Advances in Accounting Education: Teaching and Curriculum Innovations, Vol. 6, pp. 193-231.

Rezaee, Z., Lo, D., Ha, M. and Suen, A. (2016), "Forensic accounting education and practice: insights from China", Journal of Forensic and Investigative Accounting, Vol. 8 No. 1, pp. 106-119.

Sadaf, R., Oláh, J., Popp, J. and Máté, D. (2018), "An investigation of the influence of the worldwide governance and competitiveness on accounting fraud cases: a cross-country perspective", Sustainability, Vol. 10 No. 3, p. 588, doi: 10.3390/su10030588.

Sahdan, M.H., Cowton, C.J. and Drake, J.E. (2020), "Forensic accounting services in English local government and the counter-fraud agenda", Public Money and Management, Vol. 40 No. 5, pp. 380-389, doi: 10.1080/09540962.2020.1714208.

Sanchez, M.H. (2012), "The role of the forensic accountant in a medicare fraud identity theft case", Global Journal of Business Research, Vol. 6 No. 3, pp. 85-92.

Seda, M. and Kramer, B.K.P. (2008), "The emergence of forensic accounting programs in higher education”, Management Accounting Quarterly, Vol. 9 No. 3, pp. 15-23.
Forensic accounting 
JBSED

1,2

148

Seda, M. and Kramer, B.K.P. (2014), "An examination of the availability and composition of forensic accounting education in the United States and other countries", Journal of Forensic and Investigative Accounting, Vol. 6 No. 1, pp. 1-46.

Seda, M. and Kramer, B.K.P. (2015), "A comparison of US forensic accounting programs with the national institute of justice funded model curriculum", Journal of Forensic and Investigative Accounting, Vol. 7 No. 2, pp. 144-177.

Smith, G.S. and Crumbley, D.L. (2009), "How divergent are pedagogical views toward the fraud/ forensic accounting curriculum?", Global Perspectives on Accounting Education, Vol. 6, pp. 1-24.

Souza, J.L. (2017), "Using the classroom to assist students to find their fit in the forensic accounting profession", Journal of Forensic and Investigative Accounting, Vol. 9 No. 1, pp. 724-735.

Tarr, J.A., Van Akkeren, J. and Buckby, S. (2016), "Forensic accounting: professional regulation of a multi-disciplinary field", Australian Business Law Review, Vol. 44 No. 3, pp. 204-215.

Timofeyev, Y. and Jakovljevic, M. (2020), "Fraudster's and victims' profiles and loss predictors' hierarchy in the mental healthcare industry in the US", Journal of Medical Economics, Vol. 23 No. 10, pp. 1111-1122.

Tiwari, R.K. and Debnath, J. (2017), "Forensic accounting: a blend of knowledge", Journal of Financial Regulation and Compliance, Vol. 25 No. 1, pp. 73-85, doi: 10.1108/JFRC-05-2016-0043.

Van Akkeren, J. and Buckby, S. (2015), "Perceptions on the causes of individual and fraudulent co-offending: views of forensic accountants", Journal of Business Ethics, Vol. 146 No. 2, pp. 383-404, doi: 10.1007/s10551-015-2881-0.

Van Akkeren, J. and Tarr, J.A. (2014), "Regulation, compliance and the Australian forensic accounting profession”, Journal of Forensic and Investigative Accounting, Vol. 6 No. 3, pp. 1-26.

Van Akkeren, J., Buckby, S. and MacKenzie, K. (2013), "A metamorphosis of the traditional accountant: an insight into forensic accounting services in Australia", Pacific Accounting Review, Vol. 25 No. 2, pp. 188-216, doi: 10.1108/PAR-06-2012-0023.

Wang, J., Lee, G. and Crumbley, D.L. (2016), "Current availability of forensic accounting education and state of forensic accounting services in Hong Kong and mainland China", Journal of Forensic and Investigative Accounting, Vol. 8 No. 3, pp. 515-534.

Weygandt, J.J., Kieso, D.E., Kimmel, P.D., Trenholm, B., Warren, V. and Novak, L. (2019), Accounting Principles, John Wiley and Sons, New York, Vol. 2.

Williams, J.W. (2006), "Private legal orders: professional markets and the commodification of financial governance", Social and Legal Studies, Vol. 15 No. 2, pp. 209-235, doi: 10.1177/ 0964663906063575.

Yang, C.H. and Lee, K.C. (2020), "Developing a strategy map for forensic accounting with fraud risk management: an integrated balanced scorecard-based decision model", Evaluation and Program Planning, Vol. 80, p. 101780.

Yeoh, P. (2014), "Whistleblowing: motivations, corporate self-regulation, and the law", International Journal of Law and Management, Vol. 56 No. 6, pp. 459-474, doi: 10.1108/IJLMA-06-2013-0027.

Yogi Prabowo, H. (2013), "Better, faster, smarter: developing a blueprint for creating forensic accountants", Journal of Money Laundering Control, Vol. 16 No. 4, pp. 353-378, doi: 10.1108/ JMLC-05-2013-0017.

\section{Corresponding author}

Ebrahim Mansour can be contacted at: ebrahim_mansour@hu.edu.jo

For instructions on how to order reprints of this article, please visit our website:

www.emeraldgrouppublishing.com/licensing/reprints.htm

Or contact us for further details: permissions@emeraldinsight.com 